\title{
UPAYA PENINGKATAN KEMAMPUAN SISWA DALAM MENJELASKAN PERKEMBANGAN TEKNOLOGI KOMUNIKASI DAN TRANSPORTASI MELALUI PENERAPAN METODE KOOPERATIF JIGSAW
}

\author{
ARI YANTO \\ ari.thea86@gmail.com
}

\begin{abstract}
Abstrak. Tujuan dari penelitian ini adalah untuk mendeskripsikan: (1) Peningkatan kemampuan siswa dalam menjelaskan perkembangan teknologi dan transportasi melalui penerapan metode kooperatif jigsaw di SDN Winduhaji $1 \mathrm{Kec}$. Kuningan Kab. Kuningan (2) Kemampuan siswa setelah mengikuti metode kooperatif jigsaw. Penelitian ini merupakan jenis penelitian tidakan kelas dengan menggunakan pendekatan kualitatif. Subyek dalam penelitian ini adalah siswa kelas IV SDN Winduhaji $1 \mathrm{Kec}$. Kuningan Kab. Kuningan. Teknik pengumpulan data dalam penelitian ini menggunakan tes, observasi, dan dokumentasi. Prosedur penelitian tindakan kelas ini dilakukan melalui dua siklus dimana tiap siklus terdiri dari 4 tindakan Adanya peningkatan dari siklus I ke silkus II karena dalam pelaksanaan disiklus II selalu mendapatkan perbaikan yang diperoleh dari refleksi disiklus I. Berdasarkan hasil refleksi dan diskusi dengan teman sejawat tentang proses penelitian pembelajaran mata pelajaran IPS Siklus I yang telah dilakukan memperoleh suatu peningkatan, hal ini dikarenakan siswa yang telah menguasai materi sejumlah 33 siswa. Hal ini dapat dilihat dari rincian nilai yang diperoleh siswa, yaitu siswa yang memperoleh nilai 80 sebanyak 19 siswa, nilai 70 sebanyak 14 siswa, dan nilai 60 sebanyak 7 siswa. Berdasarkan hasil refleksi dan diskusi dengan teman sejawat tentang proses penelitian pembelajaran mata pelajaran IPS siklus II, terlihat adanya suatu kemajuan yang sangat signifikan, karena seluruh siswa telah menguasai materi pelajaran. Hal ini dapat dilihat dari rincian nilai yang diperoleh siswa, yaitu siswa yang memperoleh nilai 10 sebanyak 3 siswa, nilai 90 sebanyak 12 siswa, nilai 80 sebanyak 15 siswa, dan nilai 70 sebanyak 10 siswa. Dengan demikian, penelitian pembelajaran dianggap berhasil dengan baik.
\end{abstract}

Kata Kunci : metode kooperatif jigsaw, kemampuan siswa 


\section{Latar Belakang}

Pendidikan merupakan salah satu faktor penentu kelestarian dan kemajuan bangsa. Pendidikan di Indonesia terus diusahakan agar lebih maju dan bermutu. Upaya peningkatan mutu pendidikan dilaksanakan antara lain dengan mengusahakan penyempurnaan proses belajar mengajar.

Pendidikan dikatakan berkualitas apabila terjadi penyelenggaraan pembelajaran yang efektif dan efisien dengan melibatkan semua komponenkomponen pendidikan, seperti mencakup tujuan pengajaran, guru dan peserta didik, bahan pengajaran, strategi / metode belajar mengajar, alat dan sumber pelajaran serta evaluasi (Wismono, 2004:3).

Metode adalah cara yang digunakan untuk memberi kesempatan pada siswa untuk mendapatkan informasi yang dibutukan dalam rangka mencapai tujuan yang telah ditetapkan. Dalam memilih metode, guru juga harus berorientasi pada keaktifan siswa. Strategi pembelajaran lebih ditekankan pada kegiatan siswa. Guru hanya sebagai pembimbing dan fasilitator bagi siswa (Hamalik, 2003:2627).

Dalam model pembelajaran jigsaw ini siswa memiliki banyak kesempatan untuk mengemukanakan pendapat, dan mengelolah imformasi yang didapat dan dapat meningkatkan keterampilan berkomunikasii, anggota kelompok bertanggung jawab atas keberhasilan kelompoknya dan ketuntasan bagian materi yang dipelajari, dan dapat menyampaikan kepada kelompoknya (Rusman, 2008.203).

Dengan mempertimbangkan hal tersebut di atas maka penulis menyusun tugas akhir yang berjudul "Upaya Peningkatan Kemampuan Siswa Dalam Menjelaskan Perkembangan Teknologi Komunikasi dan Transportasi Melalui Penerapan Metode Kooperatif Jigsaw".

Berdasarkan latar belakang tersebut, maka diambil rumusan masalah sebagai berikut :"Bagaimana meningkatkan kemampuan siswa dalam menjelaskan perkembangan teknologi dan transportsi melalui penerapan metode kooperatif jigsaw

\section{Model Pembelajaran Kooperatif Tipe Jigsaw}

1. Definisi Model Pembelajaran Kooperatif Jigsaw

Model pembelajaran kooperatif model jigsaw adalah sebuah model belajar kooperatif yang menitik beratkan kepada kerja kelompok siswa dalam bentuk kelompok kecil, seperti yang diungkapkan Gulo (2004: 73), bahwa pembelajaran kooperatif model jigsaw ini merupakan model belajar kooperatif dengan cara siswa belajar dalam kelompok kecil yang terdiri atas empat sampai dengan enam orang secara heterogen dan siswa saling bekerja sama, saling ketergantungan positif, dan bertanggung jawab secara mandiri. Dalam model pembelajaran jigsaw ini siswa memiliki banyak kesempatan untuk mengemukakan pendapat dan mengelola informasi yang di dapat serta dapat meningkatkan keterampilan berkomunikasi, anggota kelompok bertanggung jawab atas keberhasilan kelompoknya dan ketuntasan bagian materi yang dipelajari dan dapat menyampaikan kepada kelompoknya (Wismono, 2004: 203).

Pembelajaran kooperatif tipe jigsaw merupakan tipe pembelajaran kooperatif yang mendorong siswa aktif dan saling membantu dalam menguasai materi pelajaran untuk mencapai prestasi yang maksimal. Dalam model belajar ini terdapat tahap-tahap dalam penyelenggaraannya. Pada kegiatan ini keterlibatan guru dalam proses belajar mengajar semakin berkurang dalam arti guru menjadi pusat kegiatan kelas. Guru berperan sebagai fasilitator yang mengarahkan dan memotivasi siswa untuk belajar mandiri serta menumbuhkan rasa tanggung jawab serta siswa akan merasa senang berdiskusi. Mereka dapat berinteraksi dengan teman sebayanya dan juga dengan gurunya sebagai 
pembimbing. Dalam model pembelajaran biasa atau tradisional guru menjadi pusat semua kegiatan kelas. Sebaliknya, di dalam model belajar jigsaw, meskipun guru tetap mengendalikan aturan, guru tidak lagi menjadi pusat kegiatan kelas.

Motivasi teman sebaya dapat digunakan secara efektif di kelas untuk meningkatkan, baik pembelajaran kognitif siswa maupun pertumbuhan efektif siswa. Salah satu tantangan terbesar yang dihadapi guru adalah memotivasi siswa. Guru cenderung menggunakan kompetensi untuk memotivasi siswa mereka dan sering mengabaikan strategi yang didalamnya terdapat kerjasama dan motivasi teman sebaya yang dapat digunakan untuk membantu siswa fokus terhadap prestasi akademis.

Dalam model jigsaw versi Aronson kelas dibagi menjadi suatu kelompok kecil yang heterogen yang diberi nama tim jigsaw dan materi dibagi sebanyak kelompok menurut anggota timnya. Tiaptiap tim diberikan satu set materi yang lengkap dan masing-masing individu ditugaskan untuk memilih topik mereka. Kemudian siswa dipisahkan menjadi kelompok "ahli" atau "rekan" yang terdiri dari seluruh siswa di kelas yang mempunyai bagian informasi yang sama.

Dalam pembelajaran jigsaw, siswa dikelompokkan menjadi empat-empat untuk mempelajari sebuah bab dalam sebuah buku ajar. Oleh sebab itu, bab tersebut dibagi menjadi empat bagian yang mengajak tiap anggota kelompok menjadi ahli pada satu bagian dan kemudian bertanggung jawab untuk mengajarkan anggota lain dalam kelompok tentang hal tersebut. Tahap-tahap nya adalah sebagai berikut :

Tahap 1 : Bahan Ajar

Guru memilih satu bab dalam buku ajar kemudian membagi bab tersebut menjadi bagian-bagian sesuai dengan jumlah anggota kelompok. Jadi, apabila jumlah anggota kelompok 4 orang siswa maka bab tersebut dibagi menjadi empat bagian. Setiap angota kelompok ditugasi untuk membaca dan mempelajari bagiannya pada bab tersebut. Pada tahap selanjutnya masing-masing anggota kelompok bertemu dengan ahli-ahli dari kelompok lain dalam kelas.

\section{Tahap 2 : Diskusi Kelompok Ahli}

Kelompok ahli harus melakukan pertemuan sekitar satu kali pertemuan untuk mediskusikan topik yang ditugaskan. Setiap anggota kelompok ahli harus menerima lembar kerja "ahli". Lembar kerja ahli harus memuat pertanyaanpertanyaan dan kegiatan (jika ada) untuk mengarahkan diskusi kelompok. Guru mendorong para siswa untuk menggunakan cara belajar yang bervariasi. Tujuan kelompok ini adalah mempelajari subbab tersebut dan menyiapkan ringkasan presentase untuk mengajarkan subbab tersebut kepada kelompok kecil masngmasing.

\section{Tahap 3 : Pelaporan dan Pengetesan}

Masing-masing anggota kelompok ahli kembali ke kelompok kecil masing-masng. Masing-masing anggota kelompok kecil mengajarkan topik masing-masing ke anggota lainnya dalam kelompok. Guru mendorong para siswa untuk menggunakan metode mengajar yang bervariasi. Guru mendorong anggota kelompok untuk mengajukan pertanyaan ke penyaji dan mendiskusikan lembar kerja kelompok kecil.

Setelah diskusi kelompok kecil guru menyelenggarakan tes yang mencakup materi satu bab penuh dalam waktu yang tidak lebih dari 15 menit. Seringlah menggunakan kuis-kuis dan jangan menggunakan skor tim, skor kemajuan, atau lembar berita. Cukup berikan nilai individual kepada siswa (Slavin, 1994:246).

\section{Tahap 4 : Tahap Perhargaan}

Tahap ini merrupakan tahap yang mampu mendorong para siswa untuk lebih kompak. Pada tahap ini rata-rata peningkatan kelompok dilaporkan pada cara penghargaan mingguan. Guru dapat menggunakan kata-kata khusus untuk memberikan kinerja kelompok semacam 
Bintang Sains, Kelompok Einstein, atau sebutan lainnya. Penghargaan kerja masing-masing kelompok dapat disjikan pada papan pengumuman yang melaporkan peringkat masing-masing kelompok dalam kelas. Kinerja individu yang luar biasa juga dilaporkan. Kepekaan guru sangat diperlukan dan penting dipahami bahwa menghargai siswa secara akademik dari kelompok berkemampuan rendah merupakan bagian integral keefektifan pembelajaran jigsaw. Elizabeth Cohen telah menemukan bahwa penting untuk menyadari akan para siswa yang diduga memiliki kompetensi yang konsisten rendah. Ketika siswa semacam ini menunjukkan kinerja baik, segera beri dia penghargaan khusus yang bersifat terbuka untuk kompetensi

\section{Metode}

Subjek penelitian tindakan ini dilakukan terhadap siswa kelas IV SDN di SDN Winduhaji $1 \mathrm{Kec}$. Kuningan Kab. Kuningan Tahun Ajaran 2015/2016 yang berjumlah 40 orang, terdiri dari 21 siswa dan 19 siswi. Dalam penelitian ini penulis menggunakan mata pelajaran IPS dengan penekanan pada konsep "Perkembangan Teknologi Komunikasi dan Transportasi". Tempat Penelitian dilakukan di kelas IV SDN Winduhaji $1 \mathrm{Kec}$. Kuningan Kab. Kuningan. Penelitian ini dilaksanakan dalam 2 siklus yang dilaksanakan pada tanggal 28 Maret 2016 sampai 5 April 2016 dengan jadwal pelaksanaan penelitian sebagai berikut :

\section{Desain Prosedur Perbaikan Pembelajaran}

1. Siklus I

a. Perencanaan

Perencanaan perbaikan pembelajaran sebagai upaya meningkatkan penguasaan siswa terhadap materi pembelajaran dan motivasi belajar siswa, langkah-langkah yang merupakan cara yang akan dilaksanakan dalam melakukan perbaikan pembelajaran adalah sebagai berikut :

1. Menyusun skenario perbaikan pembelajaran
2. Mempersiapkan sarana dan prasarana yang dapat menunjang terhadap kelancaran dan keberhasilan proses perbaikan pembelajaran

3. Menyusun lembar kerja siswa

4. Mempersiapkan lembar observasi baik untuk siswa maupun untuk guru selama proses perbaikan berlangsung

5. Menyusun alat evaluasi berupa soal

6. Menentukan teman sejawat untuk mengamati pelaksanaan proses perbaikan pembelajaran.

\section{b. Pelaksanaan}

Pelaksanaan pembelajaran IPS untuk meningkatkan penguasaan siswa terhadap materi pelajaran dilaksanakan melalui Penelitian Tindakan Kelas yang disusun dalam 2 siklus. Langkah-langkah dalam penyusunan perbaikan pembelajaran ialah merumuskan tujuan pertama yang perlu dilakukan guru dimaksudkan sebagai indikator hasil belajar yang ingin dicapai. Prosedur langkah-langkah perbaikan pembelajaran dapat dijelaskan sebagai berikut :

1. Melaksanakan perbaikan pembelajaran sesuai dengan rencana perbaikan pembelajaran yang telah disusun

2. Menggunakan sarana dan prasarana yang dapat mendukung terhadap kelancaran proses perbaikan pembelajaran

3. Merefleksi terhadap proses perbaikan pembelajaran

4. Mendiskusikan hasil refleksi dan observasi dengan teman sejawat untuk mengambil keputusan terhadap proses perbaikan.

c. Pengamatan / Pengumpulan Data / Instrumen

Teknik pengumpulan data dilakukan dengan mengukur kemampuan siswa melalui pemberian soal evaluasi. Instrumen yang digunakan dalam penelitian ini adalah media foto. 
Berdasarkan hasil observasi teman sejawat selama proses perbaikan pembelajaran berlangsung, aspek-aspek yang diamati oleh teman sejawat yang disusun dalam lembar observasi yang terdapat dalam lampiran laporan ini.

\section{d. Refleksi}

1. Refleksi dan observasi terhadap proses perbaikan pembelajaran

Berdasarkan hasil refleksi dan diskusi dengan teman sejawat tentang proses perbaikan pembelajaran mata pelajaran IPS pada siklus I, maka teridentifikasi faktor kekuatan dan kelemahan yang berdampak terhadap keefektifan proses tindakan perbaikan pembelajaran yang dilaksanakan. Faktorfaktor tersebut diantaranya :

a. Faktor Kekuatan

Proses tindakan perbaikan pembelajaran pada siklus I pada waktu menyampaikan materi pelajaran tentang perkembangan teknologi komunikasi dan transportasi disertai penggunaan alat peraga berupa gambar alat-alat komunikasi dan transportasi, ternyata dapat meningkatkan pemahaman siswa terhadap materi pelajaran yang dipelajarinya dibandingkan dengan tidak menggunakan alat peraga dan hanya menggunakan metode ceramah.

b. Faktor Kelemahan

Ketika proses tindakan perbaikan pembelajaran berlangsung situasi dan kondisi kelas masih pasif, masih banyak siswa yang tidak berani untuk mengajukan pertanyaan maupun menjawab pertanyaan yang diajukan oleh guru atau oleh temannya. Motivasi siswa masih belum terangsang untuk terlihat aktif dalam pembelajaran.

2. Refleksi dan observasi terhadap guru

Setelah proses tindakan perbaikan pembelajaran selesai dan menyikapi hasil evaluasi yang belum memuaskan, guru mencoba merefleksi terhadap pelaksanaan proses perbaikan kemudian hasilnya didiskusikan dengan teman sejawat. Dari hasil diskusi tersebut, terungkap kekuatan dan kelemahan guru ketika melaksanakan tindakan perbaikan, diantaranya :

\section{a. Kekuatan}

Penyampaian materi pelajaran guru sudah sesuai dengan rencana perbaikan pembelajaran yang telah disusun. Melibatkan siswa untuk aktif dalam pembelajaran dengan mengajukan pertanyaan dan hasilnya sangat positif.

\section{b. Kelemahan}

Media yang digunakan masih belum membantu terhadap pemahaman siswa sehingga siswa tidak tertarik oleh gambar tersebut apalagi usia siswa kelas IV masih berada pada tahapan operasional kongkrit. Guru masih membiarkan siswa yang tidak memperhatikan ketika guru sedang menjelaskan, metode yang digunakan belum bervariasi sehingga motivasi siswa masih pasif.

\section{Siklus II}

\section{a. Perencanaan}

Perencanaan penelitian pembelajaran pada siklus II yaitu melanjutkan rencana yang belum dilaksanakan pada siklus I, penulis mempersiapkan langkah-langkah yang merupakan cara yang akan dilaksanakan dalam melakukan perbaikan pembelajaran sebagai berikut :

1. Faktor masalah yang akan diperbaiki

Pemahaman siswa terhadap materi pelajaran sangat rendah.

2. Cara memperbaikinya

a. Menyuruh siswa untuk mempersiapkan alat-alat tulis

b. Melakukan tanya jawab sebagai bahan apersepsi untuk 
mengarahkan pemahaman siswa terhadap materi pelajaran

c. Menyampaikan tujuan pembelajaran

d. Membahas materi disertai dengan penggunaan media

e. Siswa berdiskusi untuk mengerjakan soal-soal latihan Lembar Kerja Siswa (LKS)

f. Menyampaikan materi pelajaran

g. Melaksanakan evaluasi akhir.

b. Pelaksanaan

Proses pelaksanaan pembelajaran pada siklus II masih menggunakan Penelitian Tindakan Kelas (PTK), dengan langkah-langkah tindakan perbuatan yaitu menggunakan media kongkrit berupa foto untuk memotivasi siswa supaya terlibat aktif dalam mengikuti proses pembelajaran.

c. Pengamatan / Pengumpulan Data / Instrumen

Berdasarkan hasil observasi teman sejawat selama proses perbaikan pembelajaran pada siklus II berlangsung, maka diperoleh data seperti pada lembar observasi yang terdapat dalam lampiran laporan ini.

d. Refleksi

1. Refleksi dan observasi terhadap proses perbaikan pembelajaran

Berdasarkan hasil refleksi dan diskusi dengan teman sejawat tentang proses perbaikan pembelajaran mata pelajaran IPS pada siklus II, maka teridentifikasi faktor kekuatan dan kelemahan, yaitu :

a. Faktor Kekuatan

Proses tindakan pembelajaran pada siklus II dengan menggunakan media gambar ternyata lebih meningkatkan pemahaman siswa terhadap materi pelajaran yang dipelajarinya dan motivasi siswa meningkat sehingga situasi pembelajaran menjadi efektif.

b. Faktor Kelemahan

Pada siklus II kelemahan ditemukan sangat minim, diantaranya ada 4 orang anak yang masih tidak serius atau berdiam diri ketika melakukan kerja kelompok atau berdiskusi.

2. Refleksi dan observasi terhadap guru

Guru sudah memperhatikan dan melaksanakan faktor-faktor kelemahan yang ada pada siklus I. Hasil evaluasi yang diperoleh siswa sangat memuaskan, guru mencoba merefleksi terhadap pelaksanaan proses perbaikan kemudian hasilnya didiskusikan dengan teman sejawat. Dari hasil diskusi tersebut terungkap kekuatan dan kelemahan guru ketika melaksanakan tindakan perbaikan, diantaranya :

a. Kekuatan

Penyampaian materi pelajaran guru sudah sesuai dengan rencana perbaikan pembelajaran yang telah disusun, melibatkan siswa untuk aktif dalam pembelajaran dengan memberikan contoh konkrit, menyuruh siswa untuk berdiskusi, melaporkan hasil diskusinya di depan kelas, memberikan penguatan kepada siswa yang berani tampil di depan kelas, dan hasilnya sangat positif.

b. Kelemahan

Guru merasa disibukkan untuk merencanakan, melaksanakan, merefleksi, dan berdiskusi dengan teman sejawat, sebagai bentuk meningkatkan pemahaman siswa terhadap materi pelajaran dan motivasi siswa untuk terlibat aktif dalam pembelajaran.

C. Teknik Analisis Data

Penelitian tindakan kelas untuk penelitian pembelajaran menggunakan teknik statistik deskriptif untuk menganalisis data kuantitatif. Analisis data dilakukan dengan kuantitatif, yaitu penilaian berdasar perolehan nilai akhir hasil evaluasi.

Sedangkan untuk data kualitatif yang berupa hasil pengamatan 
terhadap proses pembelajaran menggunakan teknik analisis kualitatif. Rujukannya pada penjelasan kategorisasi berdasar teori-teori pembelajaran yang digunakan.

Prosentase Nilai Mata Pelajaran IPS Data Awal, Siklus I, dan Siklus II

\begin{tabular}{|c|c|c|c|c|c|c|c|}
\hline \multirow{2}{*}{ No } & \multirow{2}{*}{ Nilai } & \multicolumn{2}{|c|}{ Awal } & \multicolumn{2}{c|}{ Siklus I } & \multicolumn{2}{c|}{ Siklus II } \\
\cline { 3 - 8 } & & $\begin{array}{c}\text { Jumlah } \\
\text { Siswa }\end{array}$ & $\begin{array}{c}\text { Prosent } \\
\text { ase (\%) }\end{array}$ & $\begin{array}{c}\text { Jumlah } \\
\text { Siswa }\end{array}$ & $\begin{array}{c}\text { Prosentas } \\
\text { e (\%) }\end{array}$ & $\begin{array}{c}\text { Jumlah } \\
\text { Siswa }\end{array}$ & $\begin{array}{c}\text { Prosentas } \\
\text { e (\%) }\end{array}$ \\
\hline 1. & 100 & - & - & - & - & 3 & 7,5 \\
\hline 2. & 90 & - & - & - & - & 12 & 30 \\
\hline 3. & 80 & 9 & 22,5 & 19 & 47,5 & 15 & 37,5 \\
\hline 4. & 70 & 18 & 45 & 14 & 35 & 10 & 25 \\
\hline 5. & 60 & 6 & 15 & 7 & 17,5 & - & - \\
\hline 6. & 50 & 2 & 5 & - & - & - & - \\
\hline 7. & 40 & 5 & 12,5 & - & - & - & - \\
\hline 8. & 30 & - & - & - & - & - & - \\
\hline 9. & 20 & - & - & - & - & - & - \\
\hline 10. & 10 & - & - & - & - & - & - \\
\hline \multicolumn{2}{|r|}{ Jumlah } & $\mathbf{4 0}$ & $\mathbf{1 0 0}$ & $\mathbf{4 0}$ & $\mathbf{1 0 0}$ & $\mathbf{4 0}$ & $\mathbf{1 0 0}$ \\
\hline
\end{tabular}

Untuk lebih jelasnya, perbedaan persentase pada tiap tahap dapat dilihat pada

Grafik

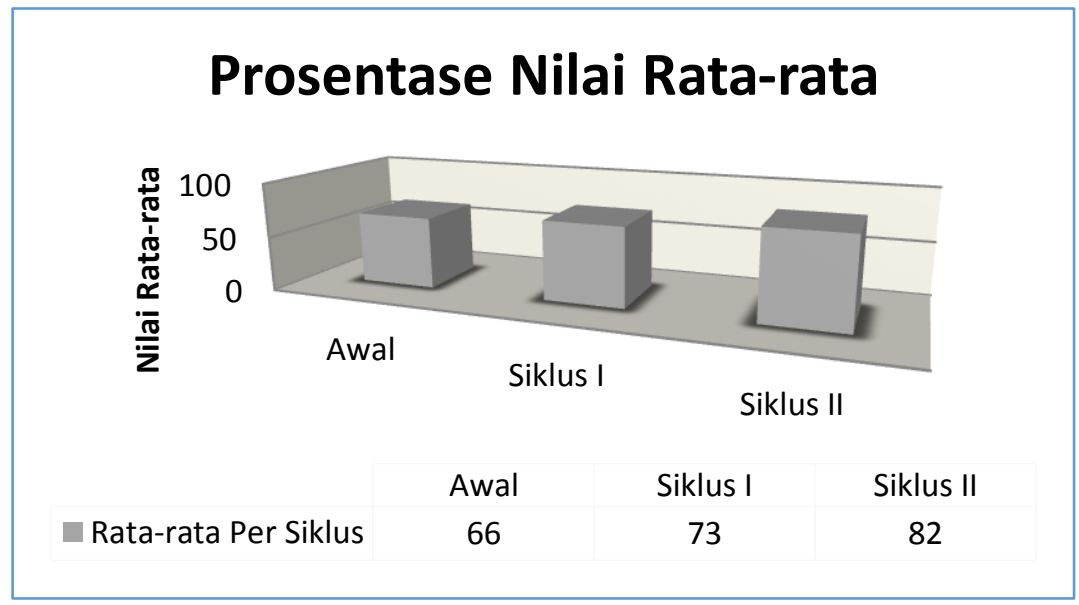

Grafik. Prosentase nilai rata-rata per siklus

Dari hasil temuan refleksi terhadap permasalahan fokus penelitian pembelajaran hasil yang meningkat dalam mencapai nilai siswa pada pembelajaran IPS meningkat.

Berdasarkan Grafik ditunjukkan terjadi peningkatan pada nilai siswa. Penguasaan konsep pembelajaran IPS mengalami peningkatan. Hal ini memperlihatkan adanya kemajuan dari hasil perbaikan pembelajaran yang dilakukan penulis.
Pada Tabel ditunjukkan bahwa pada keadaan awal terdapat 27 siswa mendapat nilai lebih dari 60, siklus I terdapat 33 siswa mendapat nilai lebih dari 60, dan pada siklus II terdapat 40 siswa mendapat nilai lebih dari 60

Setelah melakukan refleksi, maka diketahui keberhasilan dan kegagalan dari proses pembelajaran yang penulis lakukan, yaitu :

a. Keberhasilan 
- Dengan melakukan penggunaan gambar alat komunikasi dan transportasi dapat mengembangkan sikap keingintahuan siswa

- Keaktifan siswa dapat meningkatkan pemahaman siswa terhadap materi

- Sikap ingin tahu siswa tidak hanya dimiliki oleh siswa yang prestasinya bagus.

b. Kegagalan

- Masih ada siswa yang belum mempunyai sikap ingin tahu

- Belum mampu membangkitkan motivasi seluruh siswa.

\section{B. Pembahasan dari Setiap Siklus}

\section{Siklus I}

Berdasarkan hasil refleksi dan

diskusi dengan teman sejawat tentang proses penelitian pembelajaran mata pelajaran IPS Siklus I yang telah dilakukan memperoleh suatu peningkatan, hal ini dikarenakan siswa yang telah menguasai materi sejumlah 33 siswa. Hal ini dapat dilihat dari rincian nilai yang diperoleh siswa, yaitu siswa yang memperoleh nilai 8 sebanyak 19 siswa, nilai 7 sebanyak 14 siswa, dan nilai 6 sebanyak 7 siswa.

Tetapi secara keseluruhan, tujuan pembelajaran yang diharapkan belum tercapai dengan optimal. Sebagai langkah untuk menyikapinya penulis mencoba merefleksi dari tindakan perbaikan pembelajaran yang telah dilaksanakan, kemudian merencanakan kembali melakukan tindakan perbaikan pembelajaran pada siklus II.

\section{Siklus II}

Berdasarkan hasil refleksi dan diskusi dengan teman sejawat tentang proses penelitian pembelajaran mata pelajaran IPS siklus II, terlihat adanya suatu kemajuan yang sangat signifikan, karena seluruh siswa telah menguasai materi pelajaran. Hal ini dapat dilihat dari rincian nilai yang diperoleh siswa, yaitu siswa yang memperoleh nilai 10 sebanyak 3 siswa, nilai 9 sebanyak 12 siswa, nilai 8 sebanyak 15 siswa, dan nilai 7 sebanyak 10 siswa. Dengan demikian, tindakan perbaikan pembelajaran dianggap berhasil dengan baik.

Berdasarkan temuan data penelitian pada siklus I dan II, baik berkenaan dengan hasil pembelajaran dan proses pelaksanaan pmbelajaran, maka dapat dilihat ada perbedaan antara data faktual dan ideal berdasar teori yang digunakan. Meskipun terdapat peningkatan, namun tetap bisa ditingkatkan lebih baik dan lebih optimal dalam penerapan metode kooperatif Jigsaw, yakni dalam hal:

- pengelompokkan untuk setiap kelompok kerja mempertimbangkan kemampuan peserta didik

- dengan memperhatikan durasi pembelajaran yang terbatas, maka membagi kelompok dan menata ruang kelas terlebih dahulu dapat mengefektifkan kegiatan pembelajaran dengan metode kooperatif Jigsaw.

\section{Saran}

Berdasarkan penelitian yang telah dilakukan, untuk selanjutnya penulis ingin memberikan saran yang dapat membantu usaha meningkatkan prestasi belajar siswa pada mata pelajaran IPS adalah sebagai berikut :

1. Untuk siswa

Hendaknya ikut berperan aktif dalam proses pembelajaran, selalu mengerjakan tugas-tugas yang diberikan guru, dan meningkatkan usaha belajar sehingga dapat memperoleh prestasi yang diharapkan.

2. Untuk guru

Hendaknya mempersiapkan secara cermat perangkat pendukung pembelajaran dan fasilitas belajar yang diperlukan, karena sangat mempengaruhi efektifitas dan efisiensi pembelajaran yang pada akhirnya berpengaruh pada proses dan hasil belajar IPS siswa. Guru juga harus memahami dan 
memvariasikan metode yang sesuai dengan materi, yang dapat digunakan dalam proses pembelajaran sehingga siswa tidak merasa bosan.

3. Untuk sekolah

Hendaknya mengupayakan pengadaan berbagai media pe,belajaran IPS untuk semua kelas, baik bantuan maupun swadaya sekolah, sehingga lebih menunjang dalam penanaman konsep-konsep IPS secara lebih nyata sekaligus meningkatkan aktivitas belajar siswa.

\section{DAFTAR PUSTAKA}

Arends, Richardl. 1997. Classroom

Instructional Management,

New York: The

Mc Graw-Hill Company.

Buchori M. 1997. Psikologi Pendidikan 3. Bandung : Jeanmars.

Fudyartanto, Ki RBS. 2002. Psikologi

Pendidikan dengan Pendekatan Baru. Yogyakarta: Global Pustaka Ilmu.

Gulo, W. 2004. Strategi Belajar Mengajar Kooperatif Jigsaw. Jakarta: PT. Grasindo.

Hall, B. (1973). Value clarification as learning process, New York: Paulist Press.

Hamalik, Oemar. 1999. Proses Belajar Mengajar Kooperatif. Jakarta : Bumi Aksara.

Hamalik, Oemar. 2003. Kurikulum dan Pembelajaran. Jakarta : Bumi Aksara.
Hilgard, E. \& G. Bower. (1975). Theories of learning. Century psychology series. Englewood Cliffs, New York: Prentice Hall, Inc.

Moedjiono dan Dimyati. 1991. Strategi

Belajar Mengajar. Jakarta : Depdikbud,

Dirjen Dikti Proyek

Pembinaan Tenaga

Pendidikan.

Nurhadi, dkk. 2004. Pembelajaran

Kontekstual dan

Penerapannya dalam KBK.

Malang: Universitas Negeri

Malang

Slavin, R.E. 1994. Educational Psychology

: Theory and Practise. Fourt Edition.

Massachut Setts : Allyn and

Bacon.

Sudjana, Nana dan Ibrahim. 1989.

Penelitian dan Penilaian Pendidikan.

Bandung :

Sinar Baru.

Suryobroto, B. 2002. Proses Belajar Mengajar Kooperatif. Jakarta : PT. Rineka Cipta.

Sutopo. 1996. Metodologi Penelitian Kooperatif Jigsaw. Surakarta : UNS Pers.

Suyanto. 1997. Pedoman Pelaksanaan

Penelitian Tindakan Kelas (PTK)

Pengenalan

Penelitian Tindakan Kelas. Yogyakarta: Dirjen Dikti.

Wahab, A. 1998. Metodologi Pengajaran IPS. Jakarta : Karunia

Wismono, Jaka. 2004. Gembira Belajar Dengan Metode Jigsaw. Jakarta : Grasindo. 2002. Kamus Besar Bahasa

Indonesia. Jakarta : Balai Pustaka 